OPEN

SUBJECT AREAS:

PALAEONTOLOGY

PALAEOECOLOGY

Received

4 June 2014

Accepted

24 July 2014

Published

13 August 2014

Correspondence and requests for materials should be addressed to

P.G. (pgorzelak@ twarda.pan.pl)

\title{
Reassessing the improbability of a muscular crinoid stem
}

\author{
Przemysław Gorzelak', Edward Głuchowski \& Mariusz A. Salamon ${ }^{2}$
}

'Department of Biogeology, Institute of Paleobiology, Polish Academy of Sciences, Twarda Street 51/55, PL-00-81 8 Warsaw, Poland, ${ }^{2}$ Department of Paleontology and Stratigraphy, Faculty of Earth Sciences, University of Silesia, Bẹdzińska Street 60, PL-4 1200 Sosnowiec, Poland.

\begin{abstract}
Muscular articulations in modern stalked crinoids are only present in the arms. Although it has been suggested that certain coiled-stemmed fossil taxa may have been functionally adapted to utilize muscles, evidence supporting this interpretation is lacking. Here, we use cathodoluminescence and SEM to reveal the skeletal microstructure of the enigmatic coiled-stemmed taxon Ammonicrinus (Flexibilia). Based on the well-established link between skeletal microstructure and the nature of infilling soft tissues in modern echinoderms, we reconstructed the palaeoanatomy of the Middle Devonian ammonicrinids. We show that their median columnals with elongated lateral columnal enclosure extensions (LCEE) have stereom microstructure unexpectedly resembling that in the crinoid muscular arm plates. In particular, large ligamentary facets, that are present on each side of a transverse ridge, are mainly comprised of fine galleried stereom that is indicative of the mutable collagenous tissues. In contrast, fine labyrinthic stereom, commonly associated with muscles, is situated in the periphery on each side of the surface of elongated LCEE. Our findings thus strongly suggest that the muscles may have also been present in the stem of ammonicrinids. These results reassess the previous hypotheses about evolution of muscles in crinoids and provide new insights into the mode of life of Ammonicrinus.
\end{abstract}

iving stalked crinoids (Crinoidea), commonly known as sea lilies, possess muscular articulations between opposing plates only in their arms ${ }^{1}$. This type of articulation, which allows a high degree of relatively rapid - arm movements, is believed to have first evolved during the Early Devonian ${ }^{2}$. However, among many Devonian crinoid clades, only advanced cladids are known to have acquired muscular articulations in their $a^{2} s^{3}$. It has been argued that the appearance and subsequent evolutionary success of this crinoid group and their post-Paleozoic descendants may be related to the presence of their muscular arms ${ }^{4}$. Indeed, acquisition of muscles is considered a major innovative step in crinoid evolution.

In contrast to crinoid arms which may bear muscular articulations, articulations between opposing plates in the crinoid stem are exclusively non-muscular ${ }^{1}$. Any flexibility of the stem in modern crinoids is always under the control of the ligamentary mutable collagenous tissues $(\mathrm{MCTs})^{5}$. Although it has been suggested that the stems of certain coiledstemmed fossil crinoids might have been muscular ${ }^{6}$, evidence supporting this interpretation is virtually unknown ${ }^{7,8}$.

The Devonian lecanocrinid crinoid Ammonicrinus (Flexibilia) is one of the most bizzarre coiled-stemmed crinoids. This enigmatic crinoid genus has long attracted the attention of many palaeontologists because of its unusual morphology ${ }^{9-28}$. It is characterized by a xenomorphic stem comprised of distal barrel-shaped columnals, and the median-proximal columnals have characteristic lateral columnal enclosure extensions that were planispirally coiled and displayed the ability to enclose the crown, which was equipped with short arms (Fig. 2a). Furthermore, the columnals of some ammonicrinid species have a number of other unique features, including their latera that, contrary to most crinoids, are covered by echinoid-like tubercles that may bear articulated spines indicating a possible protective function ${ }^{28}$. Unsurprisingly, the mode of life of these crinoids has become the subject of a long running controversy. In contrast to the "normal", erect feeding posture of most stalked crinoids, ammonicrinids were typically considered "plate-encased" crinoids feeding in low velocity horizontal currents ${ }^{19}$. However, a planktonic lifestyle for these crinoids was also suggested by some authors ${ }^{10}$. Most recently, on the basis of theoretical considerations about functional morphology and palaeoenvironmental analysis, it was concluded that ammonicrinids were soft-bottom dwellers, feeding in low-velocity currents, possibly through a self-produced water flow mediated by the contraction the stem delivered by non-muscular mutable collagenous tissues $(\mathrm{MCT})^{28}$. In particular, a self-produced water flow might have been generated in the interior of the enrolled proximal stem by partial opening and closing of the base of the central mass. This was likely facilitated by synarthrial articulation of the ammonicrinid mesistele characterized by the presence of the two ligamentary 
facets. In this model $^{28}$, partial opening might have been enabled by stiffening of the outer ligaments of the mutable collagenous tissues (MCT), whereas closing might have been controlled by stiffening of the inner ligaments of MCT. However, although MCTs have the special ability to change their mechanical properties ${ }^{29}$, the tissue conversion from stiff to soft enabling the efficient contraction of the entire stem could have proceed rather slowly. Indeed, according to Donovan ${ }^{7}$ the snap coiling under ligamentary control as hypothesized for some Paleozoic crinoids ${ }^{6}$ would not have been possible. This suggests another possibility: ammonicrinid stem might have contained muscles. To test this hypothesis, given the well-established relationship between the skeletal microstructure and the nature of the soft tissue in modern echinoderms ${ }^{30-32}$, it is possible to reconstruct the soft tissue palaeoanatomy of ammonicrinids with microstructural characterization of their skeletons. However, diagenetic alternation commonly leads to a significant obliteration of the primary microstructural features of the echinoderm skeleton ${ }^{33}$. Recently, Gorzelak and Zamora ${ }^{34}$ introduced a promising technique, i.e., cathodoluminescence (CL), to reconstruct the original stereom microstructure in strongly recrystallized calcitic Cambrian echinoderms. Here, we use this powerful method supplemented by conventional SEM observations of well preserved specimens to characterize the skeletal microstructure of Devonian Ammonicrinus. This approach not only provides insights into the skeletal microarchitecture and palaeoanatomy of these enigmatic crinoids but also for a reassessment of the previous hypotheses about the mode of life of Ammonicrinus and evolution of muscles in crinoids.

\section{Geological setting and materials}

The crinoid material studied here comes from the GrzegorzowiceSkały section. This section is a Lower to Middle Devonian sequence situated in the eastern part of the Bodzentyn Syncline in the Łysogóry region of the Holy Cross Mountains. The Eifelian-Givetian part of the sequence, including the Skały Beds, is exposed on the eastern slope of the Dobruchna River valley in the neighborhood of Skaty village (Fig. 1). The lithologically variable Skały Beds contain a rich and diverse fauna including crinoids ${ }^{35,36}$.

The crinoid material was collected from the lower part of the Skaty Beds, from the so-called brachiopod shales $\left(=\right.$ complex $\left.\mathrm{XIV}^{37}\right)$ and

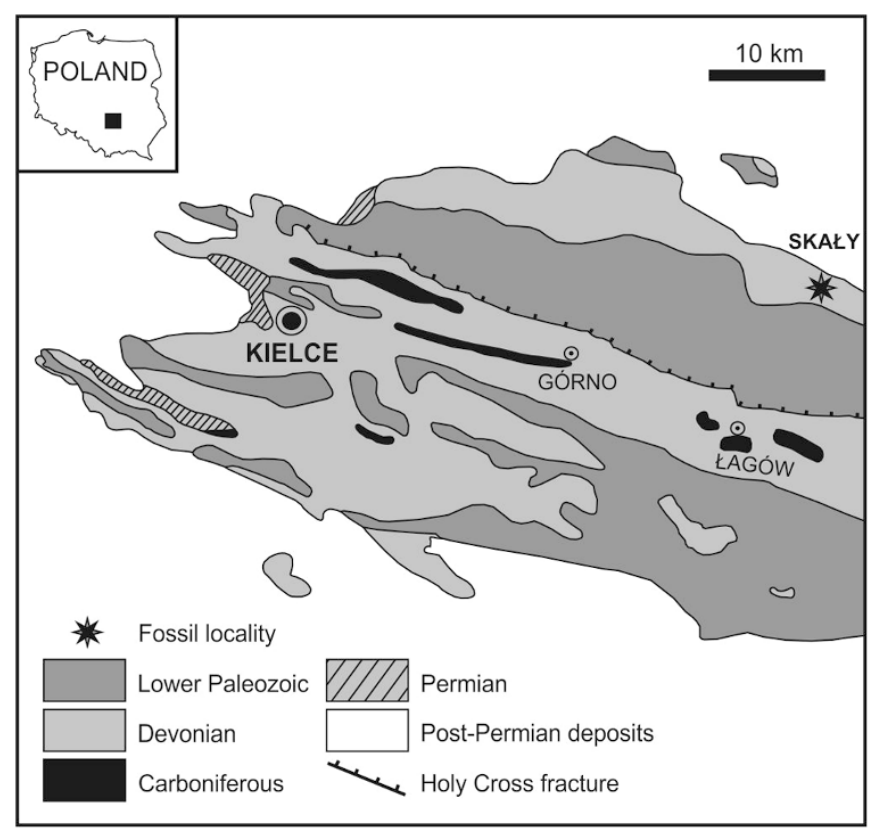

Figure 1 Geological map of western part of the Holy Cross Mountains and location of study site. Modified from ref. 35 . represents Tortodus kockelianus Zone of the upper Eifelian $(\sim 390 \mathrm{Ma})^{38,39}$.

Among the preserved crinoid ossicles are disarticulated elements of the xenomorphic column of Ammonicrinus sulcatus Kongiel. The material includes mainly large and massive columnals with elongated (Fig. 2b) or reduced (Fig. 2g) lateral columnal enclosure extensions from the middle part of stem and barrel-like columnals from the distal part of the stem (Fig. 2l).

\section{Results}

Ammonicrinid columnals analysed in this study are infilled with cement that is precipitated in optical continuity to the stereom trabeculae (Fig. 3). Thus under polarizing microscopy, the entire plate behaves as a single calcite crystal, and the stereom microstructure is hardly visible (Fig. 3a,b). EDS spot elemental analyses from selected regions revealed that the chemical composition of the stereom and cement are similar (Fig. 4), i.e., both are preserved as calcium carbonate with slightly different concentrations of Mg and Fe (Fig. 4). In BSE mode, the contrast between chemical composition of calcitic stereom and ferroan calcitic cement is somewhat more distinct (Fig. 4) although it is not very clear.

The contact between the stereom and cement is best revealed by cathodoluminescence (CL) (Fig. 3, Fig. 5). Under CL, ammonicrinid specimens have orange luminescing stereom and nonluminescent ferroan calcite (Fig. 3c, Fig. 5). The CL emission spectra of the stereom revealed emission maximum at about $615 \mathrm{~nm}$, which is indicative of $\mathrm{Mn}^{2+}$ activation in calcite (Fig. 3d). Clearly, the observed strong contrast between cement and the relic "ghost" microstructure is a consequence of the differences in concentrations of trace elements during diagenesis, i.e., $\mathrm{Mn}^{2+}$, that is the most significant activator element and $\mathrm{Fe}^{2+}$ that is the most important quencher element. This contrast, revealed by CL, allowed the primary stereom organization of investigated specimens to be reconstructed. The stereom in a few (less recrystallized) specimens was also revealed using conventional imaging in SEM (Fig. 6).

Stereom organization of median columnals. Five types of stereom can be distinguished in median columnals (Fig. 2). The articular facet on each side of a transverse ridge is mainly constructed of fine (trabeculae thickness: $2.5-6.9 \mu \mathrm{m}$ ) galleried stereom, in which pores (5.1-14.3 $\mu \mathrm{m}$ in diameter) are aligned in one direction, commonly perpendicular to the articular facet (Figs. 2d-f, i-k, Figs. 5e,h). In larger columnals, the inner, peripheral side of a well-developed facet is triangular in shape, and elongated lateral columnal enclosure extensions are covered by fine (4-7.7 $\mu \mathrm{m}$ thick) labyrinthic stereom, in which pores are irregular in size (4.1-8.8 $\mu \mathrm{m})$ and have no alignment (Figs. 2c,f, Fig. 5a,f). However, the facets of smaller columnals with strongly reduced lateral columnal enclosure extensions contain only galleried stereom (Fig. $2 \mathrm{~h}-\mathrm{k}$ ). Fine labyrinthic stereom is also recognized near the latera in the regions of the so-called echinoid-like tubercles (Figs. 2c-f, h-k; Figs. $5 \mathrm{c}, \mathrm{d}, \mathrm{i})$. The outer morphology of these tubercles resembles the so-called "glassy tubercles" of echinoderms ${ }^{40}$. However, internally they are composed of porous stereom, not compact, imperforated calcite as observed in the glassy tubercles. The latera of median columnals is usually constructed of a microperforated stereom layer with a mean thickness of $\sim 20 \mu \mathrm{m}$ (Figs. $2 \mathrm{c}-\mathrm{f}, \mathrm{h}-\mathrm{k}$, $5 \mathrm{c})$. The interior of both larger and smaller columnals is mostly comprised of coarse $(10-20 \mu \mathrm{m})$ galleried or rectilinear stereom radiating laterally (Figs. 2c-f, h-k; Figs. 5c,d,g,i). The inner side near the axial canal also contains coarse $(8.1-22.7 \mu \mathrm{m})$ labyrinthic stereom (Figs. 2c-f, h; Figs. 5b,e,h).

Stereom organization of distal columnals. Distal columnals are made of two distinct stereom fields: the biconical zone of fine galleried stereom perpendicular to the articular facet, and a much 


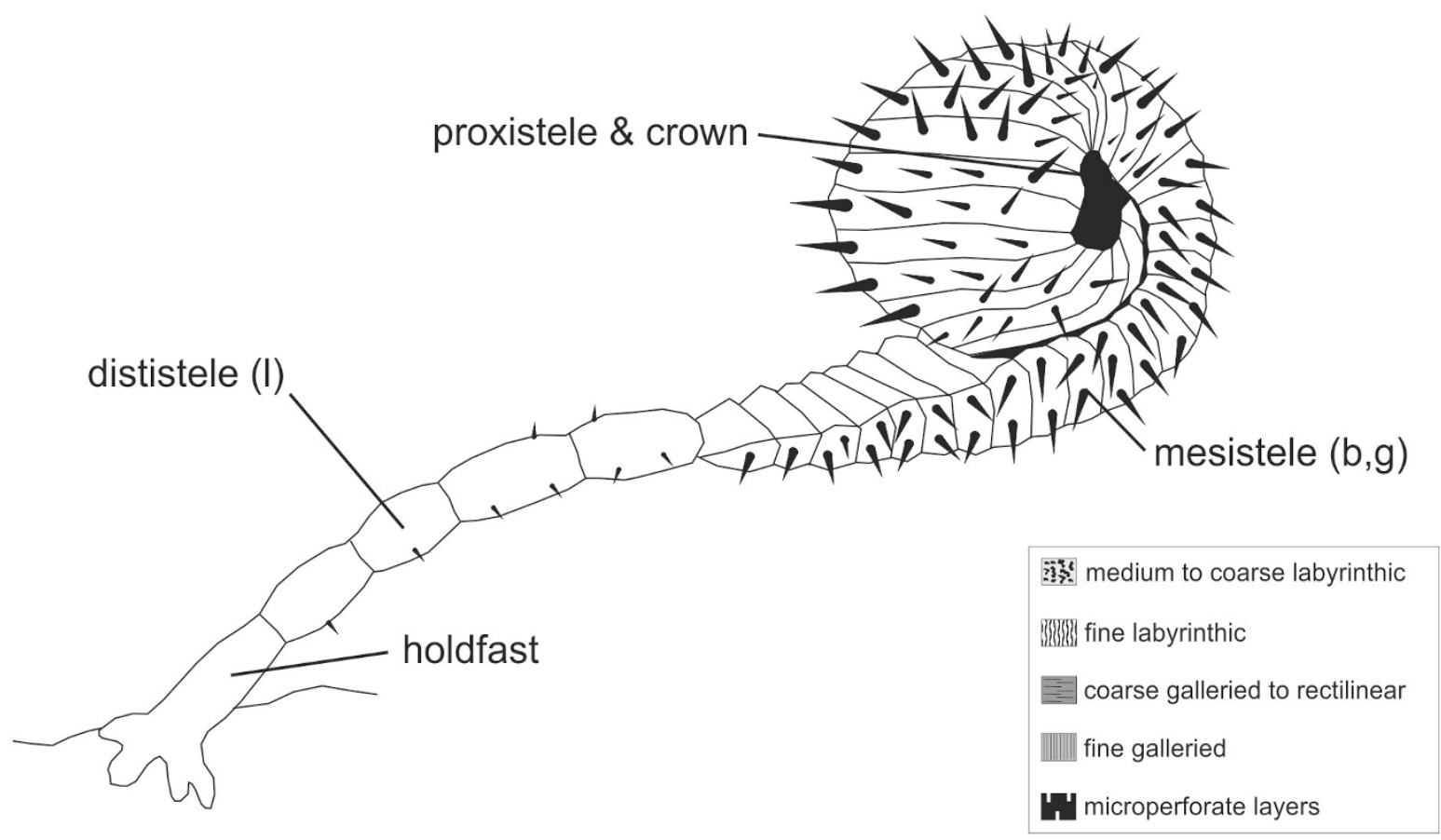

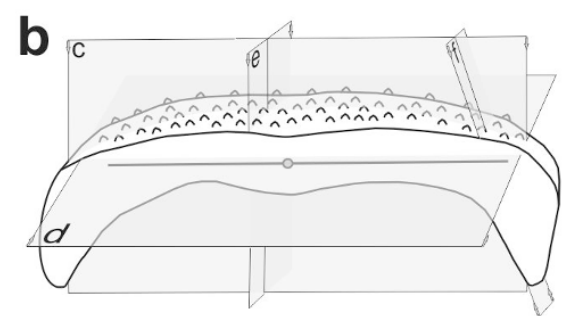

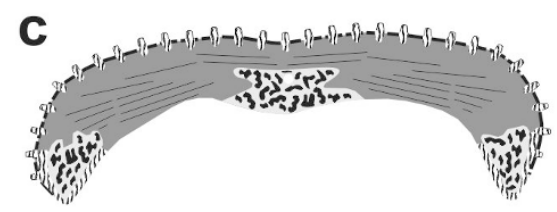

d
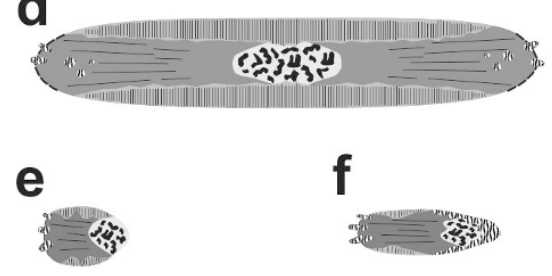
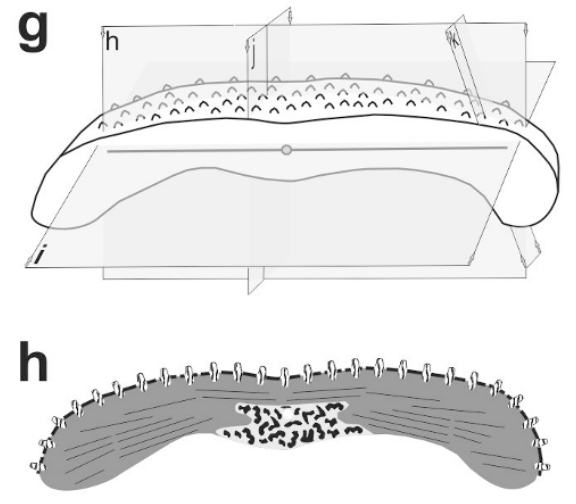

i
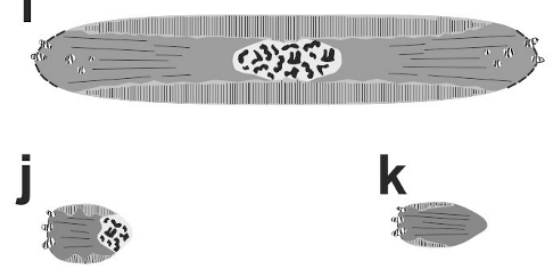

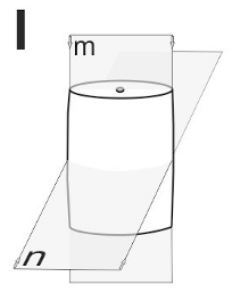

m

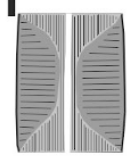

n

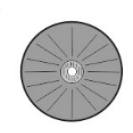

Figure $2 \mid$ Morphology and microstructure of Ammonicrinus. (a) Reconstruction of life time position (Modified from ref. 16). (b) Schematic draw of median columnal joint surface with elongated lateral columnal enclosure extension showing the orientation of investigated thin sections. (c) Distribution of stereom microstructure in transversal section. (d) Distribution of stereom microstructure in tangential section. (e) Distribution of stereom microstructure in longitudinal section. (f) Distribution of stereom microstructure in oblique-longitudinal section of the lateral columnal enclosure extension. (g) Schematic draw of median columnal joint surface with reduced lateral columnal enclosure extension showing the orientation of the investigated thin sections. (h) Distribution of stereom microstructure in transversal section. (i) Distribution of stereom microstructure in tangential section. (j) Distribution of stereom microstructure in longitudinal section. (k) Distribution of stereom microstructure in oblique-longitudinal section of the lateral columnal enclosure extension. (1) Schematic draw of distal columnal showing the orientation of the investigated thin sections. (m) Distribution of stereom microstructure in longitudinal section. (n) Distribution of stereom microstructure in transversal section.

coarser galleried to rectilinear stereom radiating laterally (Figs. 2m,n; Figs. $5 j-1)$. The galleries extending from the facet are very long, especially near the axial canal (Fig. 2m; Figs. 5j,k) with the mean pore diameter of $7.1 \mu \mathrm{m}$ and the mean trabecular thickness of
$6.2 \mu \mathrm{m}$. The coarse stereom perpendicular to the latera with the mean pore diameter of $13.9 \mu \mathrm{m}$, and the mean trabecular thickness of $19 \mu \mathrm{m}$ reaches to the outermost microperforated stereom layer with a mean thickness of $18 \mu \mathrm{m}$ (Fig. 5l). 


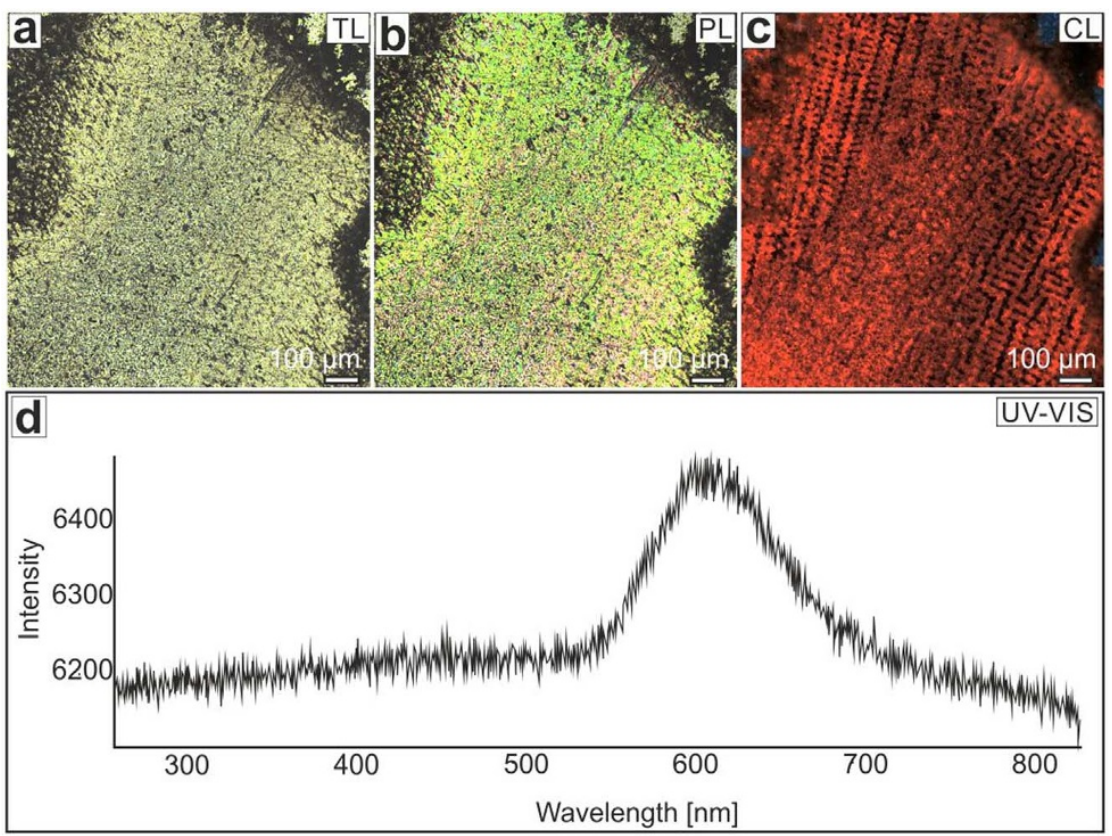

Figure 3 Photomicrographs of median columnal of Ammonicrinus (tangential section). (a) Optical (TL), (b) Polarizing (PL) and (c) Cathodoluminescence (CL) views. (d) CL-activated UV-VIS spectrum of the intense orange-red luminescent ammonicrinid columnal showing Mn ${ }^{2+}$ emission maximum at $\sim 615 \mathrm{~nm}$. Note that the stereom microstructure is greatly enhanced under cathodoluminescence.

\section{Discussion}

Among traditional proxies for identifying muslces in echinoderms, facet morphology was invoked ${ }^{2,7}$, and some studies have argued that the presence of a transverse ridge in brachials is sufficient to state that articulations are muscular. Although a similar ridge occurs on ammonicrinid columnal facets, caution is needed in such interpretations because the stem of extant bourgueticrinids, which also yields synarthrially articulating column, does not possess muscles ${ }^{5}$. Similarly, certain Paleozoic forms (such as Camptocrinus, Platycrinites, Pisocrinus), despite the presence of the transverse ridge in their brachials and/or columnals, are regarded as having had exclusively ligamentary articulations ${ }^{7}$.

It has been argued that the stereom microstructure is a much more reliable proxy for identifying the nature of the investing soft tissues than the overall morphology of the articular facet ${ }^{32}$. Indeed, as demonstrated by Macurda and Meyer ${ }^{41}$ and Smith ${ }^{30}$, there is a strong link between skeletal microstructure and the nature of infilling soft tissues in echinoderms. For example, fine galleried stereom is always indicative of through-going ligamentary collagenous fibers, whereas fine labyrinthic stereom is usually associated with the muscle fiber attachment. Following this approach, Lane and Macurda ${ }^{42}$ identified muscular articulations in Pennsylvanian crinoid brachial plates. Other microstructural studies on Paleozoic crinoid stems from different clades (Pisocrinus, Barycrinus, Gilbertsocrinus, Myelodactylid) revealed that they are comprised of a stereom exclusively associated with collagenous ligamentation, not musculature ${ }^{43-46}$. More recently, using an extensive compilation of stereom data obtained from modern echinoderms, Clausen and $S$ mith $^{32}$ reconstructed the soft tissue palaeoanatomy of Cambrian echinoderms. Following the same microstructural approach, we also inferred the soft tissue palaeoanatomy of Ammonicrinus (Figs. 7, 8).

The facets of distal and median ammonicrinid columnals with short LCEE, as in the stem of modern crinoids, are made up almost entirely of galleried stereom that is indicative of collagen fibres binding adjacent columnals (Fig. 7). In contrast, median columnals with elongated LCEE also have fine labyrinthic stereom that coats the innermost (peripherial) surface of LCEE. In many species of recent crinoids, this stereom type is characteristic for muscle attachment
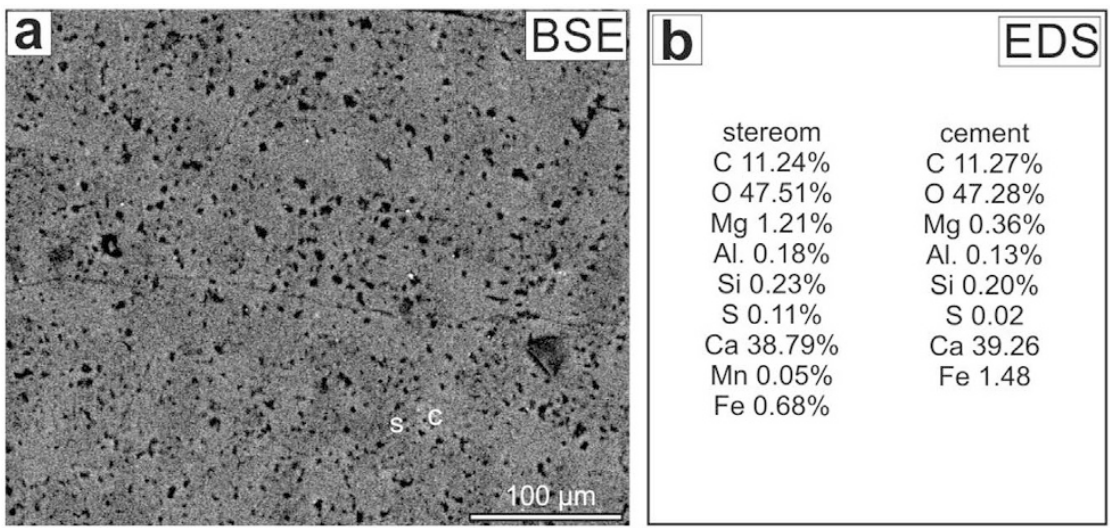

Figure 4 $\mid$ Results of geochemical analyses of Ammonicrinus. (a) SEM back-scattered electron (BSE) image of the polished ammonicrinid columnal showing the contrast between materials of lower (darker areas=stereom) versus higher atomic numer (lighter areas=cement). (b) Results of EDS analyses of the stereom (s) and cement (c). 

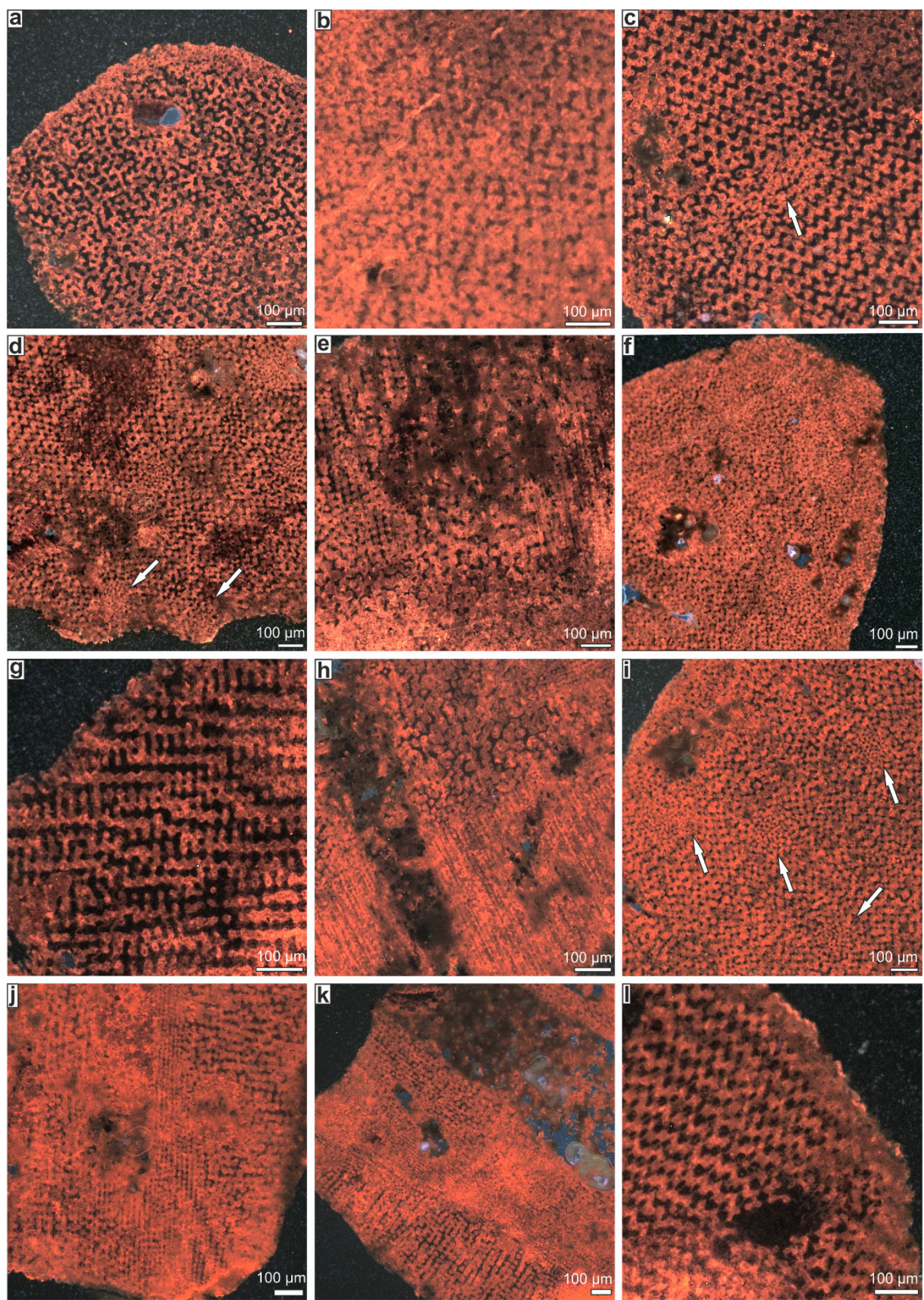

Figure 5 Cathodoluminescence (CL) photomicrographs of median (a-i) and distal (j-1) columnals of Ammonicrinus. (a) Transversal section showing medium to fine labyrinthic stereom near the periphery of the plate margin (region of the lateral columnal enclosure extension). (b) Transversal section showing the medium to coarse labyrinthic stereom in the centre of the section. (c) Transversal section showing coarse rectilinear and fine labyrinthic stereom (arrow) in the periphery of the plate margin (region close to the centre of the articular surface). (d) Longitudinal section close to the lateral columnal enclosure extension showing coarse rectilinear and/or galleried stereom and fine labyrinthic stereom (arrows) near the echinoid-like tubercles in the periphery of the plate margin. (e) Longitudinal section of the articular surface showing fine galleried stereom underlain by coarse labyrinthic stereom. (f) Oblique-longitudinal section of the lateral columnal enclosure extension showing medium to fine labyrinthic stereom. (g) Tangential section showing coarse rectilinear stereom in the periphery of the plate margin. (h) Tangential section showing coarse labyrinthic stereom underlain by fine galleried stereom near the axial canal. (i) Tangential section showing coarse labyrinthic to rectilinear stereom and fine labyrinthic stereom (arrows). (j) Longitudinal section showing fine galleried stereom (lower left) and coarse galleried to rectilinear stereom (upper right). (k) Longitudinal section showing fine galleried stereom near the lumen and perpendicular coarse galleried to rectilinear stereom near the periphery of the plate margin. (l) Longitudinal section showing coarse galleried to rectilinear stereom and microperforate layers in the periphery of the plate margin. 


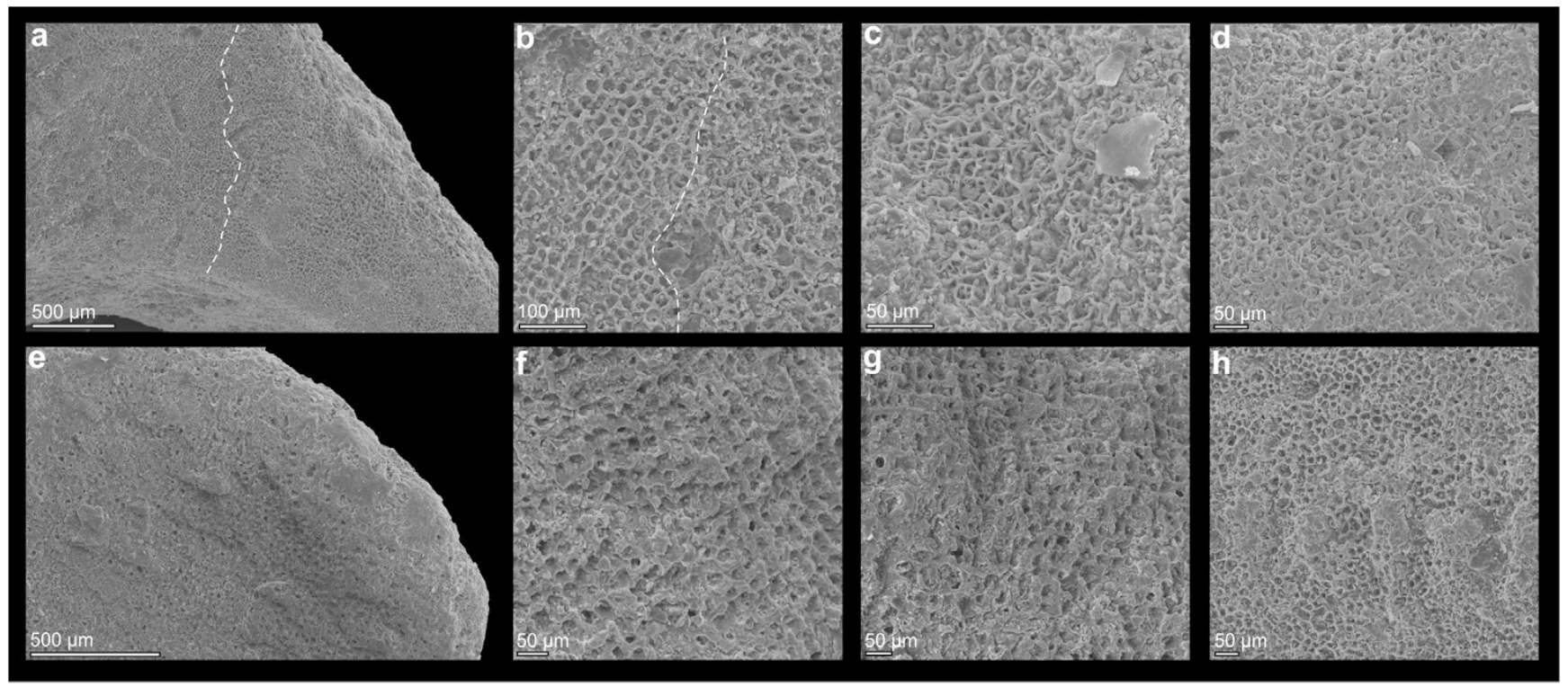

Figure 6 Microstructural organization of the facet surface of median ammonicrinid columnals with elongated (a-d) and reduced (e-h) lateral columnal enclosure extensions in SEM. (a) Boundary (dotted line) between fine galleried (left) and fine labyrithic (right) stereom. (b) Higher magnification of (a). (c, d) Higher magnification of fine labyrithic stereom. (e) Medium galleried stereom. (f, g) Higher magnification of (e). (h) Fine galleried stereom of the articular surface.

(Fig. 7). Only very rarely, ligaments are known to be also associated with labyrinthic stereom ${ }^{47}$.

The fine labyrinthic stereom indicative of muscles is also present in the regions close to the so-called echinoid-like tubercles that may bear articulated spines. This implies that the spines of Ammonicrinus could have been highly movable and were under the control of muscles. The other skeletal areas of both median and distal columnals (the interior and latera) are almost entirely composed of coarser, clearly structural (Fig. 7), galleried to rectilinear, labyrinthic and microperforate stereom.

Apart from morphological/microstructural criteria for recognizing soft tissues in echinoderms, taphonomic methods were also proposed $^{4}$. These methods rely on the fact that the muscular articulations are taphonomically less resistant to disarticulation than exclusively ligamentary articulations. Difference in the disarticulation style is evident in the present material. In particular, ammonicrinid columnals were found exclusively as isolated plates, whereas all other crinoids (camerates and inadunates) - traditionally regarding as having had exclusively ligamentary symplexial articulations between columnals, are commonly preserved as pluricolumanls, i.e. fragments of articulated stems ${ }^{19}$. Thus, the observed disarticulation gradient is consistent with microstructural data suggesting the presence of muscles in some median columnals of Ammonicrinus. The flexure of ammonicrinid stem commonly observed in complete specimens from other Devonian localities may be also indicative of muslces. Indeed, according to Ausich and Baumiller ${ }^{4}$ crinoids bearing muscles are expected to have post-mortem flexure, whereas crinoids bearing ligaments are normally preserved straight.

Taken together, all of the traditional proxies (including the morphology of the facet, the stereom microstructure and taphonomy) imply the presence of muscles in some of the median ammonicrinid columnals. On the basis of this new evidence, it is possible to evaluate critically the current hypothesis about the "stem-pumping" mode of life of Ammonicrinus.

In Ammonicrinus sulcatus analyzed in this study, the smaller columnals of the mesistele are interconnected with longer ones, which according to the new microstructural data might have contained muscles (Fig. 8). Following this hypothesis, at least the rapid contraction/closing of the stem could have been indeed possible, but

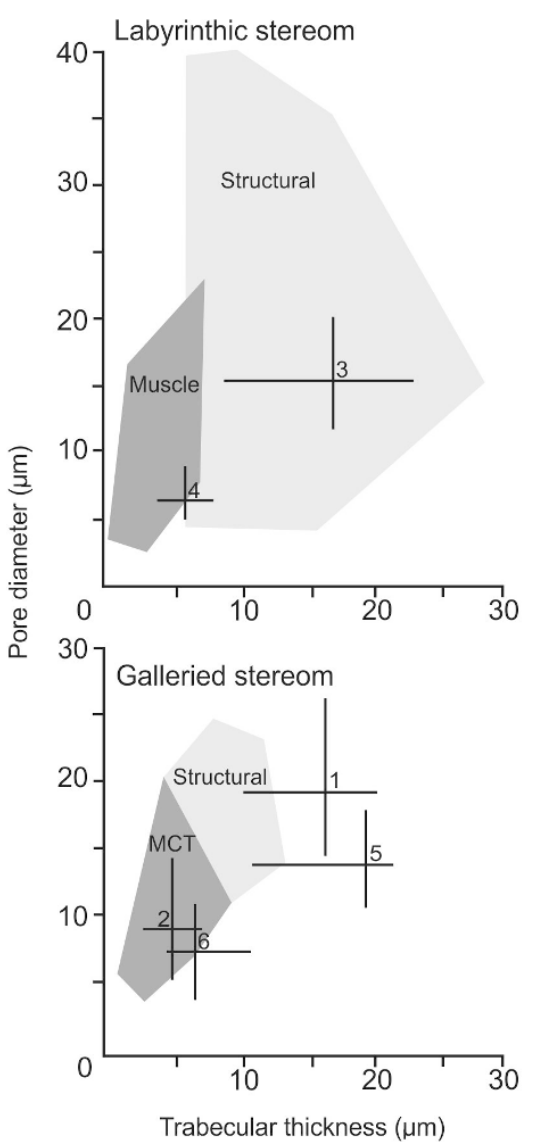

Figure $7 \mid$ Stereom fields in recent echinoderms. Taken from ref. 32. Dark shaded areas correspond to the stereom fields indicative of muscles and mutable collagenous tissues (MCT). The range and mean of the six stereom types of Ammonicrinus are indicated. 1-4 stereom types identified in median and proximal columnals. 5-6 stereom types identified in distal columnals. 
a

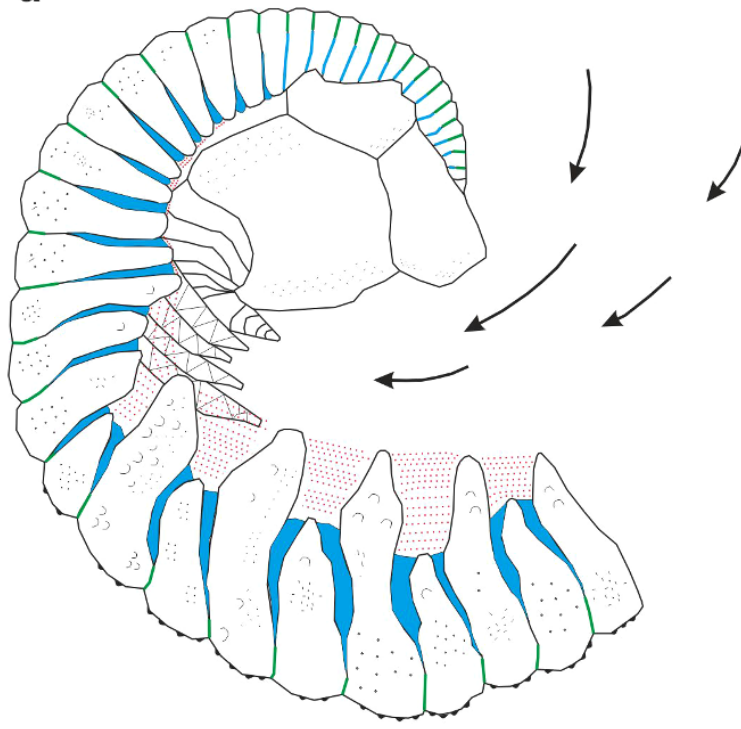

b
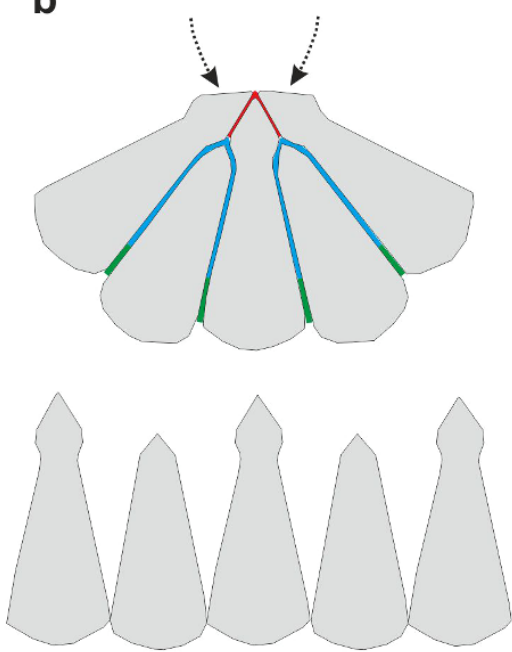

Figure 8 Reconstruction of life time position of Ammonicrinus. (a) Enclosure of the ammonicrinid crown in response to the external stimuli. (b) Schematic sketches of LCEE (lateral columnal enclosure extensions) of the mesistele in coiled (above) and uncoiled (below) positions. Modified from ref. 28. Inner ligaments (blue), outer ligaments (green), muscles (red).

it was controlled by muscles, not by MCT as previously hypothe$\operatorname{sized}^{28}$. On the other hand, bellow-like partial opening might have been enabled by the outer MCTs which could have been stayed taut when the muscles contracted and following the relaxation of muscles, the stem could have been snapped back by its tensionally loaded ligaments. However, although this hypothesis cannot be excluded, because of the relatively small surface area of muscles compared to the area of MCTs on the remainder of the columnal facet, this remains speculative. It seems obvious that the opening of the stem would have been much more passive than closing. The opening could have only been facilitated by water currents or slow MCTs motion. Similar situation can be observed in the arms of living crinoids, where there are only two small orally-located fields for the attachment of the adoral muscles and larger aboral ligaments holding the arms flexed aborally. Given the above, the feeding of ammonicrinids by stempumping mechanism ${ }^{28}$ should be viewed with caution. It seems reasonable that the ability to rapidly enclose the ammonicrinid crown was not connected with feeding but rather with protection against external stimuli such as predators ${ }^{48}$.

A key conclusions from the presented data is that muscles might have not been necessarily confined to the crinoid arms. Importantly, it seems that muscular articulations must have been acquired independently in the Devonian flexible crinoid Ammonicrinus. So far, it has been widely accepted that muscles have evolved only once, during the Early Devonian ${ }^{2}$. Among various crinoid clades, only advanced cladids and their post-Paleozoic descendants are believed to have developed muscles. Our study shows that representatives of another crinoid clade (Flexibilia) might have also evolved muscles as connecting tissue between adjacent plates. The question concerning why two independent crinoid clades (which diverged in the early Paleozoic) utilized muscles at around the same time (during the Devonian) is difficult to answer. The presence of muscles certainly served a significant advantage for feeding, locomotion and predator avoidance. As highlighted above, at least in the case of ammonicrinids, the necessity to cover the tiny crown by coiling the stem and the development of spines, could be particularly linked to the increased predation pressure during the so-called Middle Paleozoic Marine Revolution (MPMR $)^{49-53}$. During this time, diversification of various groups of predators (placoderms, sarcopterygian fishes, platyceratid gastropods) took place, resulting in anti-predatory adaptations among benthic invertebrates ${ }^{49-51}$.

\section{Methods}

52 variously oriented thin sections of several distal and median columnals (Fig. 2) polished down to about $25 \mu \mathrm{m}$ were coated with carbon and examined with a cathodoluminescence (CL) microscope equipped with a hot cathode at the Institute of Paleobiology of the Polish Academy of Sciences in Warsaw. The CL images were recorded with Kappa video camera. CL-emission spectra of selected specimens were analysed using a UV-VIS spectograph. The following parameters were used for both CL microscopy and spectroscopy: an electron energy $=14 \mathrm{keV}$, a beam current $=$ 0.1-0.2 mA, and integration times for CL-emission spectra of luminescent samples $=100 \mathrm{~s}$.

A few additional thin sections were analysed with the aid of the Energy Dispersive Spectroscopy performed on a Scanning Electron Microscope Philips XL-20 coupled with the EDS detector ECON 6, system EDX-DX4i at the Institute of Paleobiology of the Polish Academy of Sciences in Warsaw using the following parameters: accelerating voltage $=25 \mathrm{kV}$, working distance $=34 \mathrm{~mm}$, a beam diameter $\sim 5 \mu \mathrm{m}$. The microstructure of the articular surface of a few well preserved median columnals was also SEM investigated.

The specimens are housed at the Institute of Paleobiology, Polish Academy of Sciences, Warsaw (ZPALV.42D/1-52).

1. Hess, H. \& Messing, Ch. Treatise on Invertebrate Paleontology. Part T, revised, Echinodermata 2, volume 3, Crinoidea Articulata. Lawrence, KS, USA. (Paleontological Institute, The University of Kansas, 2011).

2. Van Sant, J. F. Crawfordsville crinoids. In Crawfordsville (Indiana) crinoid studies. (Van Sant J. F. \& Lane, N. G. eds.) 34-136 (University of Kansas Paleontological Contributions Article 7, 1964).

3. Ubaghs, G. Skeletal morphology of fossil crinoids. In Treatise on Inuertebrate Paleontology, Part T, Echinodermata. (Moore, R. C. \& Teichert, C., eds.) T58-T216 (Geological Society of America and University of Kansas Press, New York and Lawrence 2(1), 1978).

4. Ausich, W. I. \& Baumiller, T. K. Taphonomic method for determining muscular articulations in fossil crinoids. Palaios 8, 477-484 (1993).

5. Grimmer, J. C., Holland, N. D. \& Messing, C. G. Fine structure of the stalk of the bourgueticrinid sea lily Democrinus conifer (Echinodermata: Crinoidea). Mar. Biol. 81, 163-176 (1984).

6. Seilacher, A. \& Macclintock, C. Crinoid anchoring strategies for soft-bottom dwelling. Palaios 20, 224-240 (2005).

7. Donovan, S. K. The improbability of a muscular crinoid column. Lethaia 22, 307-315 (1989).

8. Donovan, S. K. Crinoid anchoring strategies for soft-bottom dwelling (Seilacher \& Macclintock). Palaios 21, 397-399 (2006).

9. Springer, F. Unusual forms of fossil crinoids. Proc. U. S. Nat. Mus. 67, 1-137 (1926).

10. Krause, P. G. 1927. Über Ammonicrinus aus dem Mitteldevon der Eifel. Z. Dtsch. Geol. Gesell. 79, 448-456 (1927).

11. Ehrenberg, K. Die "Nebenformen" der Crinoiden, ihre stammesgeschichtliche Entwicklung und Bedeutung. Paleobiologica 7, 257-324 (1930).

12. Wolburg, J. Bau und Biologie von Ammonicrinus dolifformis sp. nov. Jahrb. Geol. Landesanst. 58, 230-241 (1938). 
13. Wolburg, J. Zur Frage der Lebensweise der eingerollten Crinoiden. Zentralbl. Mineral. Geol. Paläontol. Abt. B 7, 254-261 (1938).

14. Wanner, J. Die Krinoiden des Rheinischen Devons. Rheinische Heimatpflege 13, 27-38 (1943).

15. Wanner, J. Die Analstruktur von Ammonicrinus Springer nebst Bemerkungen über Aberranzen und Anomalien bei Krinoiden. Neues Jahrb. Geol. P. M. 5, 231-236 (1954).

16. Ubaghs, G. Ammonicrinus Springer, Crinoidea Flexibilia du Dévonien moyen d'Allemagne. Senckenb. 33, 203-226 (1952).

17. Yakovlev, N. N. \& Ivanov, A. P. Marine crinoids and blastoids of the Carboniferous and Permian deposits of Russia [in Russian]. Trudy Vsesoüznogo Naučno-Issledovatel'skogo Geologičeskogo Instituta 11, 1-142 (1956).

18. Kongiel, R. Nowy gatunek Ammonicrinus i jego wystepowanie w Polsce. Pr. Muz. Ziemi 2, 31-40 (1958).

19. Piotrowski, A. Genus Ammonicrinus Crinoidea, from the Middle Devonian of the Holy Cross Mountains, Poland. Acta Palaeontol. Pol. 22, 205-219 (1977).

20. Moore, R. C. Flexibilia. In Treatise on Invertebrate Paleontology. Part T, Echinodermata 2. (Moore, R. C. \& Teichert, C. eds.) T759-T812 (The Geological Society of America and The University of Kansas, Boulder 1-3, 1978).

21. Haude, R. Mechanik, Morphogenese und Palökologische Bedeutung der "Pelmatozoen"-Stiele. In Paläontologische Kursbücher, 1: Funktionsmorphologie. (Rief, W.-E. ed.) 187-203 (Paläontologische Gesellschaft, München, 1981).

22. Głuchowski, E. Crinoid assemblages in the Polish Givetian and Frasnian. Acta Palaeontol. Pol. 38, 35-92 (1993).

23. Hotchkiss, F. H. C., Prokop, R. J. \& Petr, V. Isolated vertebrae of brittlestars of the Family Klasmuridae Spencer, 1925 (Echinodermata: Ophiuroidea) in the Devonian of Bohemia (Czech Republic). J. Czech Geol. Soc. 44, 329-333 (1999).

24. Le Menn, J. \& Jaouen, P. A. Nouvelles espèces d'Ancyrocrinus et d'Ammonicrinus, crinoïdes à pédoncule spécialisé du Dévonien armoricain (Brest, France). C. $R$ Palevol. 2, 205-212 (2003).

25. Hauser, J. Ammonicrinus (Crinoidea, Flexibilia) aus dem Paläozoikum von Deutschland (Eifel, Sauerland) und dem Heilig-KreuzGebirge (Polen) 52 (Privately published by the author, 2005).

26. Hauser, J., Landeta, F. G. \& Savill, J. J. Ammonicrinus wanneri SPRINGER, 1926 (Crinoidea, Flexibilia) from the Portilla Formation, Givetian (Cantabrian Mountains, Province Leon, Northern Spain). In Crinoiden aus dem Unter- und Mittel- devon von Asturien und Leon (Nordspanien). (Hauser, J. \& Landeta, F. G. eds.) 54-58 (Privately published by the authors, Bonn, 2009).

27. Prokop, R. J. Ammonicrinus bulbosus sp.n. (col.) (Crinoidea, Flexibilia) from the LowerDevonian Koněprusy Limestone, Barrandian area (Czech Republic). J. Nat. Mus., Nat. Hist. Ser. 177, 161-164 (2009).

28. Bohatý, J. Revision of the flexible crinoid genus Ammonicrinus and a new hypothesis on its life mode. Acta Palaeontol. Pol. 56, 615-639 (2011).

29. Ribeiro, A. R. et al. New Insights into Mutable Collagenous Tissue: Correlations between the Microstructure and Mechanical State of a Sea-Urchin Ligament PLoS ONE 6(9), e24822. doi:10.1371/journal.pone.0024822 (2011).

30. Smith, A. B. Stereom microstructure of the echinoid test. Spec. Pap. Palaeontol. 25, 1-81 (1980).

31. Smith, A. B. Biomineralization in echinoderms. In Skeletal biomineralization: patterns, processes, and evolutionary trends. (Carter, J. G. ed.) 413-443 (Van Nostrand Reinhold, New York, 1990)

32. Clausen, S. \& Smith, A. B. Palaeoanatomy and biological affinities of a Cambrian deuterostome (Stylophora). Nature 438, 351-354 (2005).

33. Dickson, J. A. D. Diagenesis and crystal caskets: echinoderm Mg calcite transformation, Dry Canyon, New Mexico, USA. J. Sediment. Res. 71, 764-777 (2001).

34. Gorzelak, P. \& Zamora, S. Stereom microstructures of Cambrian echinoderms revealed by cathodoluminescence (CL). Palaeontol. Electron. 17, 1A; 17p; palaeoelectronica.org/content/2014/611-cambrian-stereom (2014).

35. Głuchowski, E. Epibionts on upper Eifelian crinoid columnals from the Holy Cross Mountains, Poland. Acta Palaeontol. Pol. 50, 315-328 (2005).

36. Gorzelak, P., Rakowicz, Ł., Salamon, M. A. \& Szrek, P. Inferred placoderm bite marks on Devonian crinoids from Poland. N. Jb. Geol. Paläont. Abh. 259, 105-112 (2011).

37. Pajchlowa, M. Dewon w profilu Grzegorzowice - Skały. Biuletyn Instytutu Geologicznego 122, 145-154 (1957).

38. Malec, J. \& Turnau, E. Middle Devonian conodont, ostracod and miospore stratigraphy of the Grzegorzowice-Skały section, Holy Cross Mountains, Poland. B. Pol. Acad. Sci-Earth. 45, 67-86 (1997).
39. Narkiewicz, K. \& Narkiewicz, M. Mid Devonian carbonate platform development in the Holy Cross Mts. area (central Poland): new constraints from the conodont Bipennatus fauna. N. Jb. Geol. Paläont. Abh. 255, 287-300 (2010).

40. Gorzelak, P., Salamon, M. A., Lach, R., Loba, M. \& Ferré, B. Microlens arrays in the complex visual system of Cretaceous echinoderms. Nat. Commun. 5:3576 doi: 10.1038/ncomms4576 (2014).

41. Macurda, Jr, D. B. \& Meyer, D. L. The microstructure of the crinoid endoskeleton. Paleontol. Contrib. Univ. Kansas Pap. 74, 1-22 (1975).

42. Lane, N. G. \& Macurda, D. B., Jr. New evidence for muscular articulations in Paleozoic crinoids. Paleobiology I, 59-62 (1975).

43. Ausich, W. I. The functional morphology and evolution of Pisocrinus (Crinoidea: Silurian). J. Paleontol. 51, 672-686 (1977).

44. Ausich, W. I. Functional morphology and feeding dynamics of the Early Mississippian crinoid Barycrinus asteriscus. J. Paleontol. 57, 31-41 (1983).

45. Riddle, S. W., Wulff, J. I. \& Ausich, W. I. Biomechanics and stereomic microstructure of the Gilbertsocrinus tuberosus column. In Echinoderm Biology. (Burke, R. D., Mladenov, P. V., Lambert, P. \& Parsley, R. L., eds.) 641-648 (A.A. Balkema, Rotterdam, 1988).

46. Donovan, S. K. \& Franzen-Bengtson, C. Myelodactylid crinoid columnals from the Lower Visby Beds (Llandoverian) of Gotland. GFF 110, 69-79 (1988).

47. Holland, N. D., Grimmer, J. C. \& Wiegmann, K. The structure of the sea lily Calamocrinus diomedeae, with special reference to the articulations, skeletal microstructure, symbiotic bacteria, axial organs, and stalk tissues (Crinoidea, Millericrinida). Zoomorphology 110, 115-132 (1991).

48. Hess, H., Ausich, W. I., Brett, C. E. \& Simms, M. J. Fossil Crinoids 1-275 (Cambridge University Press, Cambridge, 1999).

49. Meyer, D. L. \& Ausich, W. I. Biotic interactions among recent and among fossil crinoids. In Biotic interactions in Recent and fossil benthic communities (Tevesz, M.J.S. \& McCall, P.L., eds.) 377-427 (Plenum, New York, 1983).

50. Signor, P. W. \& Brett, C. E. The mid Paleozoic precursor to the Mesozoic marine revolution. Paleobiology 10, 229-236 (1984).

51. Gahn, F. J. \& Baumiller, T. K. Infestation of Middle Devonian (Givetian) camerate crinoids by platyceratid gastropods and its implications for the nature of their biotic interaction. Lethaia 36, 71-82 (2003).

52. Sallan, L. C., Kammer, T. W., Ausich, W. I. \& Cook, L. A. Persistent predator-prey dynamics revealed by mass extinction. Proc. Natl. Acad. Sci. USA 108, 8335-8338 (2011).

53. Salamon, M. A., Gorzelak, P., Niedźwiedzki, R., Trzęsiok, D. \& Baumiller, T. K. Trends in shell fragmentation as evidence of mid-Paleozoic changes in marine predation. Paleobiology 40, 14-23 (2014).

\section{Acknowledgments}

This work was funded by the National Science Centre (NCN) grant no DEC-2011/03/N/ ST10/04798 and was performed in the NanoFun laboratory co-financed by the European Regional Development Fund within the Innovation Economy Operational Programme POIG.02.02.00-00-025/09.

\section{Author contributions}

P.G., E.G. and M.A.S. designed research. E.G. carried out field excavation. P.G. conducted microstructural analyses. All authors contributed to the discussion and writing of the paper.

\section{Additional information}

Competing financial interests: The authors declare no competing financial interests.

How to cite this article: Gorzelak, P., Głuchowski, E. \& Salamon, M.A. Reassessing the improbability of a muscular crinoid stem. Sci. Rep. 4, 6049; DOI:10.1038/srep06049 (2014)

This work is licensed under a Creative Commons Attribution-NonCommercialNoDerivs 4.0 International License. The images or other third party material in this article are included in the article's Creative Commons license, unless indicated otherwise in the credit line; if the material is not included under the Creative Commons license, users will need to obtain permission from the license holder in order to reproduce the material. To view a copy of this license, visit http:// creativecommons.org/licenses/by-nc-nd/4.0/ 